Scientific Journal. ISSN 2595-9433

Volume 3, Number 1, Article n. 6, January/June D.O.I. http://dx.doi.org/10.35418/2526-4117/v3n1a6

Received: 11/03/2020 - Accepted: 12/13/2020

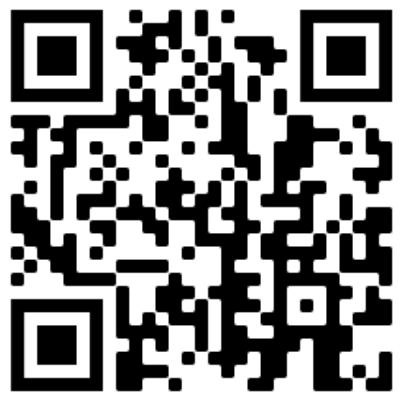

\title{
QUALI-QUANTITATIVE GENETIC DISSIMILARITY OF SOYBEAN
}

Natã Balssan Moura ${ }^{1}$, (D) Ivan Ricardo Carvalho ${ }^{1 *}$, (D) Danieli Jacoboski Hutra $^{1}$, (D) Robison Davi Patias Furlan ${ }^{1}$, (D) Guilherme Mallmann², (D) Guilherme Stasiak$^{2}$, (D) Dassaiévis Gonzatto Maciel², (D) Wilson Leonardo Farias Melo², Pedro Felipe Lopes ${ }^{2}$, (1) Francine Lautenchleger ${ }^{3}$

1 Universidade Regional do Noroeste do Estado do Rio Grande do Sul, Ijuí, RS, Brazil;

2 Centro de Pesquisa e Resultados Agronômicos Missões, Santo Ângelo, RS, Brazil;

3 Universidade do Centro-Oeste, Guarapuava, PR, Brazil.

*Corresponding author: Ivan Ricardo Carvalho (carvalho.irc@gmail.com)

\begin{abstract}
This study aimed to assess genetic dissimilarity and based on the qualitative and quantitative characteristics of 52 soybean cultivars grown in the Northwest Region of the state of Rio Grande do Sul. The experiment was conducted at the Center for Research and Agronomic Results of the Missions (CEPRAM). The experimental design used was randomized blocks with treatments arranged in four replications. Soybean qualitative attributes were measured, being the maturity group, flower color, pod color, seed shape, tegument color, anthocyanin pigmentation in the hypocotyl, pubescence color, pubescence density, hilum color, seed brightness and biotechnological event. Together, quantitative attributes were measured in ten plants per experimental unit, such as yield, number of pods per plant, number of grains per plant, grain mass per plant and thousand seed mass. The most productive cultivars were P95R90 IPRO, BMX Raio IPRO, NS 5445 IPRO, P95R30 IPRO, P95Y02 IPRO, TMG 7058 IPRO and DM 5958 IPRO. Yield correlates positively with the number of pods, number of grains, grain mass and thousand seed mass. The dendrogram for the quantitative characteristics and the decision tree showed that the formation of the groups and the grain yield were determined mainly by the grain mass and the thousand seed mass. Among the components of variance and genetic parameters, the variables thousand grain mass, grain mass and yield are influenced by $59 \%, 32 \%$ and $29 \%$ respectively by genetic effects.
\end{abstract}

Keywords: Glycine $\max$ L., strategic position, genotype, multivariate models. 


\section{Introduction}

Soybean (Glycine $\max$ L.) is one of the most cultivated oilseeds in the world, due to its great importance for the economy, commercialization and agriculture. Soy by-products are used in human food, mainly through oil, in animal feed and extraction of biofuels (Aguiar et al., 2020; Guimarães et al., 2016). Brazil has reached a production of 120 million tons of grains, with an increase of $5.1 \%$ in relation to the 2018/2019 crop season (CONAB, 2020). Despite the fact that Rio Grande do Sul was subjected to climatic adversities, the state presented itself with the third highest national productivity.

Soybean productivity is influenced by several factors, such as climatic conditions, geographical location, sowing times, cultural practices, as well as the positioning of cultivars according to the relative maturity group (Silva et al., 2018). The crop is characterized as a short-day plant and responsive to the photoperiod, that is, it needs an accumulation of light to complete its phenological stages, with a specific name for each cultivar (Zanon et al., 2018). This characteristic and the advancement of breeding enabled the crop to expand to the most varied regions of Brazil (Szareski et al., 2018).

The choice of the cultivar to be sown is one of the first decisions that growers must make during estate planning. Currently, there are hundreds of cultivars available on the market, these being specific regarding fertility, branching potential, biotechnological events, tolerance to insect pests, phytopathogenic fungi, nematodes and bacterioses (Dorneles et al., 2020). These cultivars are positioned through soybean macroregions in Brazil, called South, Center-South, Southeast, Central-West and North/Northeast. In which, each is subdivided into 20 edaphoclimatic microregions (Aguila et al., 2020).

This subdivision aims to group the cultivars according to their characteristics weighted by the peculiarities of the growing environment, based on latitude, temperatures and rainfall, photoperiod and soil classification. Due to the adjustment of agricultural scenarios to demand assertive specifications for soybeans, this study aimed to assess genetic dissimilarity and based on the qualitative and quantitative characteristics of 52 soybean cultivars grown in the Northwest Region of the state of Rio Grande do Sul.

\section{Material and methods}

The experiment was conducted at the Center for Research and Agronomic Results of the Missions (CEPRAM), located at $28^{\circ} 23^{\prime} 17.82$ "S and $54^{\circ} 19$ '13.74" $\mathrm{W}$ at an altitude of 831 meters, located in Entre-Ijuís - Rio Grande do Sul, Brazil, with soil classified as typical dystrophic red Latosol (Oxisol) (Streck et al., 2008), and humid subtropical Cfa environment according to Köeppen. The experimental design used was randomized blocks with treatments arranged in four replications, the experimental units formed by 40 square meters. The treatments correspond to 52 cultivars, which are: BMX Delta IPRO, DM 57i52 IPRO, P 95R90 IPRO, CZ 15B70 IPRO. BMX Zeus IPRO, BMX Raio IPRO, NS 5445 IPRO, P 95R30 IPRO, DM 53 i54 IPRO, P 95Y02 IPRO, NEO 530 IPRO, NS 5258 RR, FTR 4153 IPRO, HO Amambay IPRO, BRS 5601 RR, NS 5700 IPRO, BRS 5804 RR, TMG 7058 IPRO, AG 3570 IPRO, P95R95 IPRO, BS 2606 IPRO, DM 5958 IPRO, BRS 6203 RR, CZ 26B42 IPRO, P96Y90 RR, AG 3590 IPRO, NS 6909 IPRO, HO Jacuí IPRO, NS 5909 RR, NS 6010 IPRO, BMX Fibra IPRO, FPS 1859 RR, TMG 7363 RR, C 2626 IPRO, HO Pirapó IPRO, SYN 1365 RR, TMG 7067 IPRO, BMX Compacta IPRO, M 6410 IPRO, SYN 15630 IPRO, M 5947 IPRO, NS 6601 IPRO, DM 66168 IPRO, LG 60174 IPRO, TMG 2364 IPRO, TMG 7061 IPRO, FPS 1867 IPRO, TMG 2165 IPRO, TMG 7260 IPRO, SYN 1561 IPRO, NEO 610 IPRO and TMG 7368 IPRO.

These being recommendded for macroregion 102 of Rio Grande do Sul, they were sown on November 18, 2019 and harvested on March 23, 2020. The sowing density was 14 seeds per linear meter for all cultivars, with fertilization of $380 \mathrm{~kg} \mathrm{ha}^{-1}$ of NPK (11-30-20) and at 17 days after sowing, topdressing was performed with $100 \mathrm{~kg}$ $\mathrm{ha}^{-1}$ of $\mathrm{KCl}$. Phytosanitary management was carried out to minimize the biotic effects on the result of the experiment. 
Soybean qualitative attributes were measured, being the maturity group (RMG), flower color (FC), pod color (CL), seed shape (SS), tegument color (TGC), anthocyanin pigmentation in the hypocotyl (APH), pubescence color (PBC), pubescence density (PBD), hilum color (HC), seed brightness (SB) and biotechnological event (BTEC). Together, quantitative attributes were measured in ten plants per experimental unit, such as yield (GY, $\mathrm{kg} \mathrm{ha}^{-1}$ ) number of pods per plant (NP, units), number of grains per plant (NG, units), grain mass per plant (GM, g) and thousand seed mass (TSM, g).

The obtained data were submitted to the assumptions, through the tests of normality and homogeneity of the residual variances and additivity of the statistical model, then the analysis of variance at $5 \%$ probability was used to identify the variability attributed to the effect of soybean cultivars. For the characters that showed signifycance, the Scott-Knott average cluster test at 5\% probability was used.

With the need to identify the trend of association between the characters, the linear correlation for all variables (qualitative - Spearman, quantitative - Pearson) that presented significance based on the $t$ test at $5 \%$ probability was used. The average Euclidean algorithm was also applied, obtaining the matrix of genetic distances that serves as the basis for the UPGMA cluster, showing the qualitative and quantitative dendrogram. In order to understand the possible causes and the grain yield profiles of soybean cultivars, the Machine Learning algorithm based on the decision tree methodology was used, for which grain yield was determined as dependent and the other quantitative characters were considered explanatory. Deviance analysis at $5 \%$ probability based on the $\mathrm{x}^{2}$ test was used, where the characters that showed significant maximum likelihood ratio (LRT) provided the estimates of the variance components and genetic parameters. These being estimated using the restricted maximum likelyhood (REML) method, using the statistical model: $y=X r+Z g+e$ where: $y$ : vector of data, $\mathrm{r}$ : effect of repetitions (fixed), g: are the genotypic effects (random), and: are the residues (random). Subsequently, genotypic variance $\left(\sigma^{2} G\right)$, residual variance $\left(\sigma^{2} E\right)$, phenotypic variance $\left(\sigma^{2} P\right)$, broad sense heritability for total genotypic effects
$\left(\widehat{H}^{2} g\right)$, average heritability of genotypes $\left(\widehat{H}^{2} \mathrm{mg}\right)$, accuracy (Aclon), coefficient of genotypic variation $(\mathrm{CVg})$, residual coefficient of variation $(\mathrm{CVe})$ and the general average were estimated. Statistical analyzes were performed using the $\mathrm{R}$ and RStudio software.

\section{Results and discussion}

During the period of growth and development of the crop, rainfall rates (Figure 1) were lower than the minimum required, water deficiency in the 2019/2020 crop season was evident in all soybean micro-regions of Rio Grande do Sul. For soybeans to demonstrate their full productive potential, it needs approximately $800 \mathrm{~mm}$ well distributed throughout its cycle (Carvalho et al., 2013; Zanon et al., 2018). On this occasion, rainfall was less than the needs with seasonality in the distribution of water supply throughout the cycle, with deficits coinciding with flowering and grain filling (Schaparini et al., 2020).

Analyzing the qualitative characters, the linear correlation aims to demonstrate the correlation between two variables (Figure 2), being the relative maturity group ( $\mathrm{RMG}$ ), has a negative correlation with the color of the pod and pubescence, these attributes express contrary definetions. The color of the flower is positively associated with pigmentation with hypocotyl anthocyanin, hilum color and biotechnological event, in contrast, inverse relationships with peroxidase activity. The correlation between the color of the flower and the pigmentation of the hypocotyl is defined pleiotropically and is classically defined as stable and determinant morphological genetic markers for the soybean breeding (Carvalho et al., 2017a; Carvalho et al., 2018).

The pod color (PC) is positively associated with the reaction of peroxidase and pubescence of the pod. For the seed shape (SS) there was a positive correlation with the biotechnological events, and opposite relationships with the color of pubescence, positive associations of the color of the hypocotyl (APH), with the color of the hilum, biotechnological event and the reaction with peroxidase. The reaction of the peroxidase enzyme is evident as a biochemical genetic marker commonly used to differentiate soybean cultivars that show phenotypically similar morphological genetic markers (Klaumann et al., 2015). 




Figure 1. Daily rainfall during the 2019/2020 crop season in Entre-Ijuís - RS, Brazil.

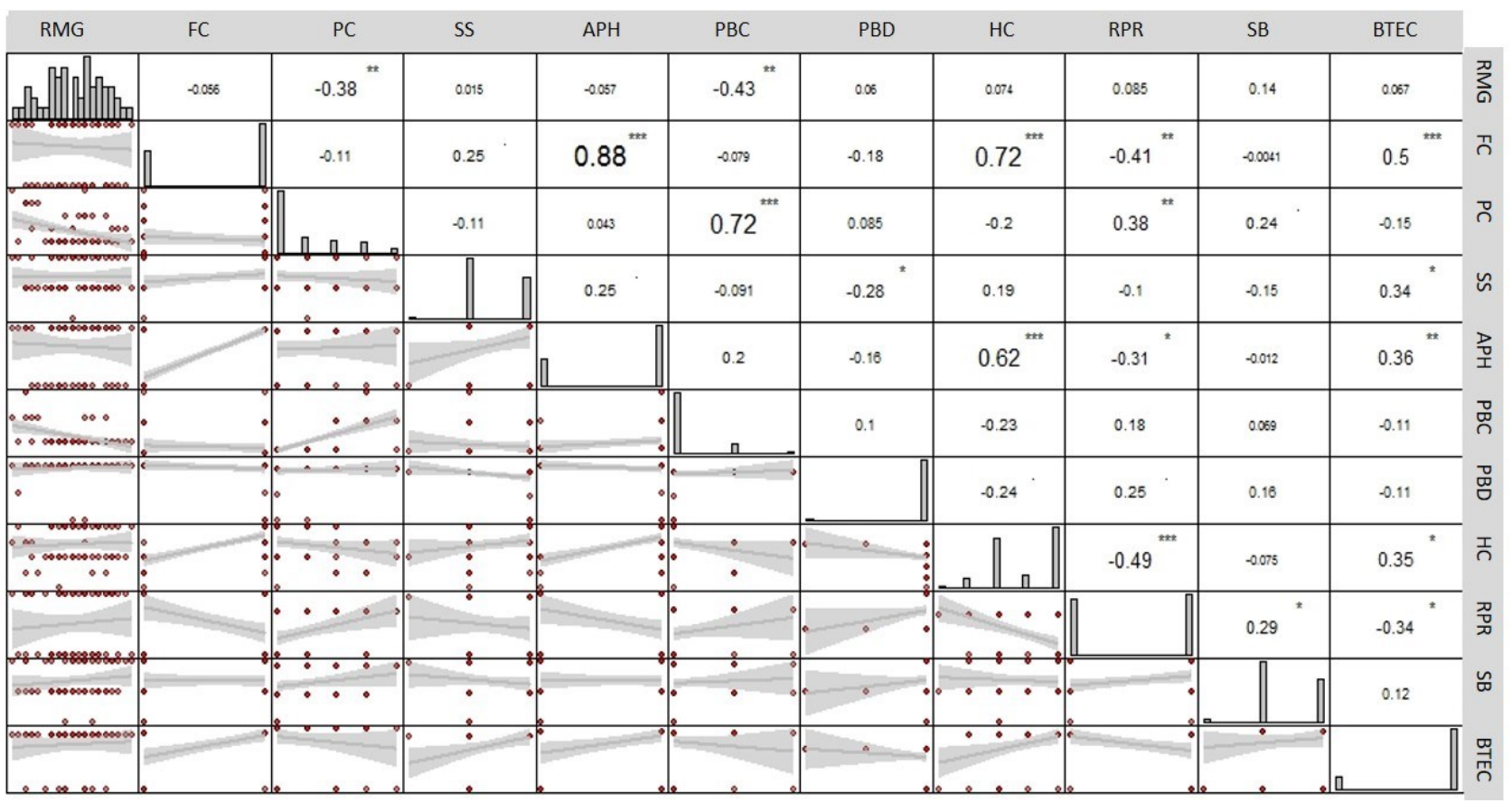

Figure 2. Linear correlation for the qualitative characteristics of 52 soybean cultivars.

* significance based on $5 \%$ by t test. Relative maturity group (RMG), flower color (FC), pod color (PC), seed shape (SS), hypocotyl pigmentation $(\mathrm{APH})$, pubescence color $(\mathrm{PBC})$, pubescence density (PBD), hilum color (HC), peroxidase reaction (RPR), seed brightness (SB), Biotechnology (BTEC).

The dendrogram (Figure 3a) represents the similarity between the cultivars regardless of the qualitative characteristics analyzed, where the cultivars were divided into five large groups, for the blue ones the cultivars that showed similarities were NEO 610 IPRO (51) and M 5947 IPRO (41), CZ 26B42 (24) and M 6410 IPRO (39), HO Pirapó IPRO (35) and BMX Compacta IPRO (38), NS 6601 IPRO (42) and TMG 2165 IPRO (48), TMG 7067 IPRO (37) and TMG 7368 IPRO (52) and SYN 1365 RR (36) and SYN 15630 IPRO (40). Due to the similarity of the characteristics presented between these cultivars, mainly the maturity group, it is characteristic for later culti-vars. For the red group, only the cultivar NS 6909 IPRO (27) fit this group, due to its maturity group, which is superior to the other cultivars present in the study. Another group was orange in color, and the cultivars that showed equivalence were 
LG 60174 IPRO (44) and NS 6010 IPRO (30), BRS 6203 RR (23) and TMG 7363 IPRO (33), P 95R30 IPRO (8) and C 2626 IPRO (34), P 95R95 IPRO (20) and BS 2606 IPRO (21) and P 95R90 IPRO (3) and TMG 7061 IPRO (46).

Due mainly to the similarity of the maturity group, which is charac-terized by medium cycle cultivars, in addition to the other characteristics. The large green colored group presented subgroups with similar cultivars HO Amambay IPRO (14) and NS 5700 IPRO (16), DM 57 i52 IPRO (2) and CZ 15B70 IPRO (4), AG 3570
IPRO (19) and DM 5958 IPRO (22), TMG 7058 IPRO (18) and AG 3590 IPRO (26) and BRS 5804 IPRO (17) and FPS 1859 RR (32).

The main characteristic among them was the maturity group, with an early cycle. Another group was purple in color with the cultivars NS 5258 RR (12) and FTR 4153 IPRO (13) and BMX Zeus IPRO (5) and NS 5445 IPRO (7) and the last group was dark blue with the cultivar BMX Raio IPRO (6) that presented the 5.0 maturity group, for these last groups the determinant is the maturity group.

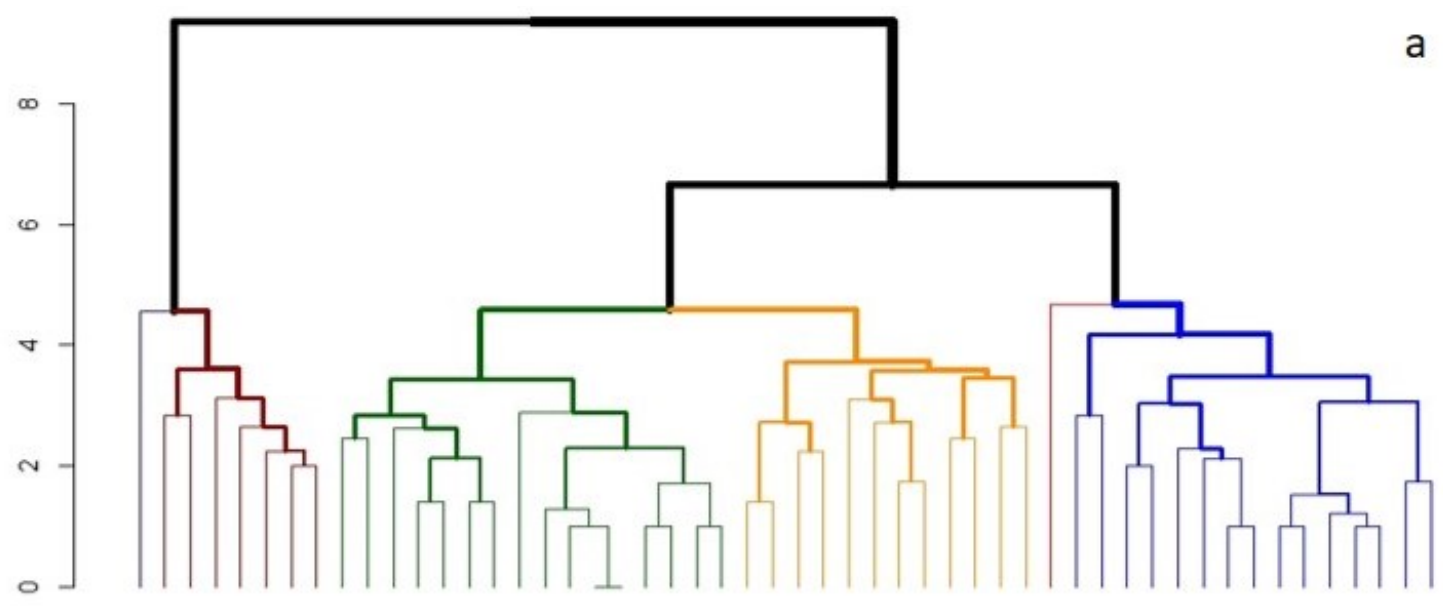

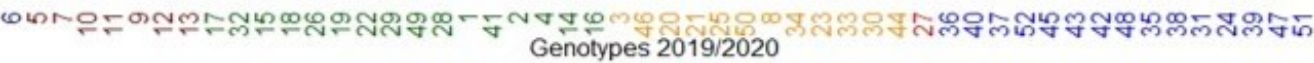

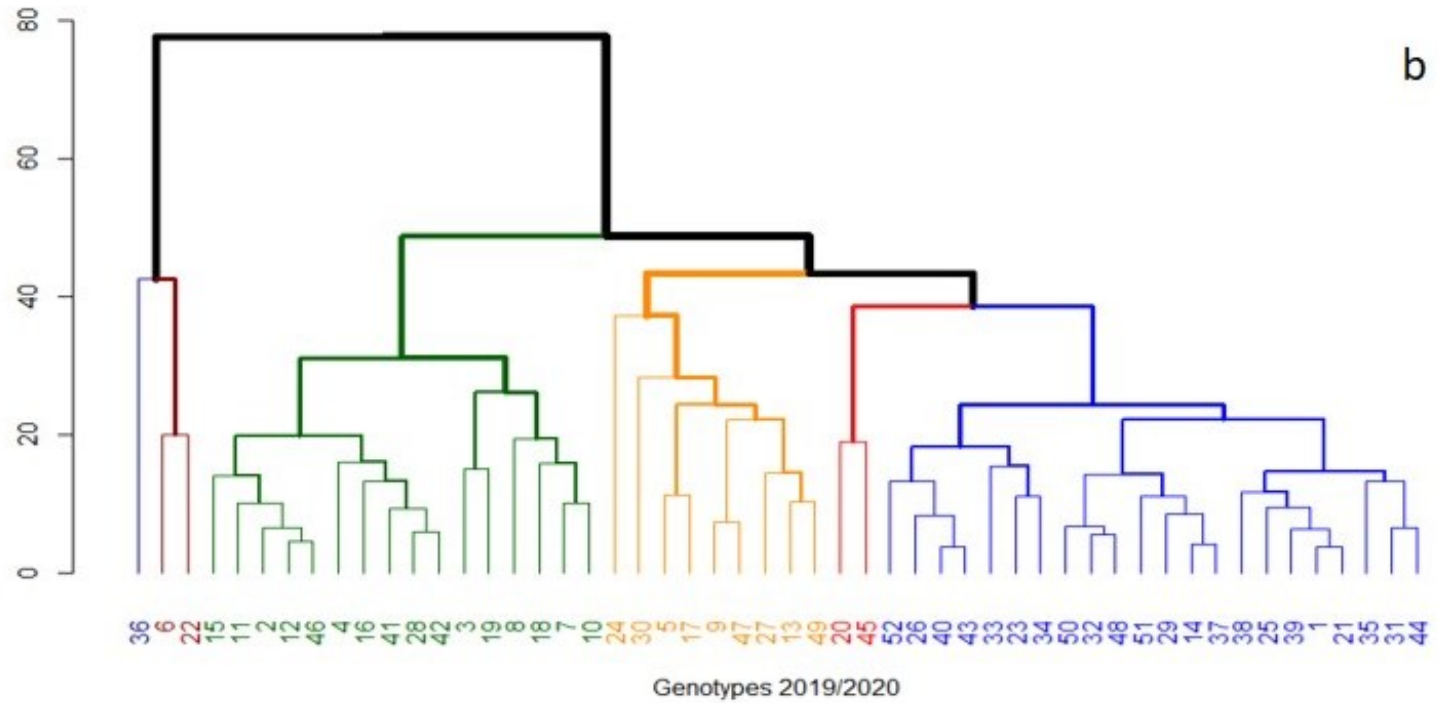

Figure 3. Dendrogram obtained by the matrix of multivariate distances for qualitative characters (a) and quantitative characters (b) of 52 soybean cultivars.

BMX Delta IPRO (1), DM 57i52 IPRO (2), P 95R90 IPRO (3), CZ 15B70 IPRO (4). BMX Zeus IPRO (5), BMX Raio IPRO (6), NS 5445 IPRO (7), P 95R30 IPRO (8), DM 53 i54 IPRO (9), P 95Y02 IPRO (10), NEO 530 IPRO (11), NS 5258 RR (12), FTR 4153 IPRO (13), HO Amambay IPRO (14), BRS 5601 RR (15), NS 5700 IPRO (16), BRS 5804 RR (17), TMG 7058 IPRO (18), AG 3570 IPRO (19), P95R95 IPRO (20), BS 2606 IPRO (21), DM 5958 IPRO (22), BRS 6203 RR (23), CZ 26B42 IPRO (24), P96Y90 RR (25), AG 3590 IPRO (26), NS 6909 IPRO (27), HO Jacuí IPRO (28), NS 5909 RR (29), NS 6010 IPRO (30), BMX Fibra IPRO (31), FPS 1859 RR (32), TMG 7363 RR (33), C 2626 IPRO (34), HO Pirapó IPRO (35), SYN 1365 RR (36), TMG 7067 IPRO (37), BMX Compacta IPRO (38), M 6410 IPRO (39), SYN 15630 IPRO (40), M 5947 IPRO (41), NS 6601 IPRO (42), DM 66 i68 IPRO (43), LG 60174 IPRO (44), TMG 2364 IPRO (45), TMG 7061 IPRO (46), FPS 1867 IPRO (47), TMG 2165 IPRO (48), TMG 7260 IPRO (49), SYN 1561 IPRO (50), NEO 610 IPRO (51) and TMG 7368 IPRO (52). 
The analysis of variance revealed signifycance at $5 \%$ probability (Table 1 ) for the variables grain yield (GY), number of pods per plant (NP), number of grains per plant (NG), grain mass per plant (GM) and thousand seed mass (TSM).

The results of the averages (Figure 4 a) for the variable number of pods per plant (NP), the cultivars that stood out were P95R90 IPRO (3), BMX Raio IPRO (6), P95R30 IPRO (8), DM 5958 IPRO (22) and SYN 1365 RR (36). The number of pods is influenced by several factors, but mainly by the balance between the amount of flowers that develop until the pods form, being related to the number of nodes and the branches of the plant (Navarro et al., 2002).

The latter being one of the characteristics strongly present in these cultivars. For the number of grains per plant (Figure $4 \mathrm{~b}$ ) the same cultivars showed higher average, because this characteristic is highly influenced by the number of pods per plant. For the grain mass variable (Figure $4 \mathrm{c}$ ) the cultivars that showed the highest results were BMX Raio IPRO (6), NS 5445 IPRO (7), P95R30 IPRO (8), DM 5958 IPRO (22), SYN 1365 RR (36).

Table 1. Summary of the analysis of variance for the quantitative agronomic characters in the 52 soybean cultivars.

\begin{tabular}{|c|c|c|c|c|c|c|}
\hline \multicolumn{7}{|c|}{ Mean squares } \\
\hline SV & DF & NP (unid.) & NG (unid.) & GM (g) & TSM(g) & GY (kg ha-1) \\
\hline Cultivars & 51 & $2006.91^{*}$ & $12735.22^{*}$ & 291.03* & $5166.23^{*}$ & $3263.75^{*}$ \\
\hline Blocks & 3 & 666.24 & $8024.1^{*}$ & $135.25^{*}$ & 111.29 & $1715.54^{*}$ \\
\hline CV(\%) & - & 36.94 & 30.83 & 33.66 & 11.44 & 33.14 \\
\hline Average & - & 55.4 & 134.52 & 15.5 & 114.82 & 56.9 \\
\hline
\end{tabular}

* Significant at 5\% probability. Source of variation (SV), degrees of freedom (DF), number of pods per plant (NP), number of grains per plant (NG), grain mass per plant (GM), thousand seed mass (TSM) and grain yield (GY).

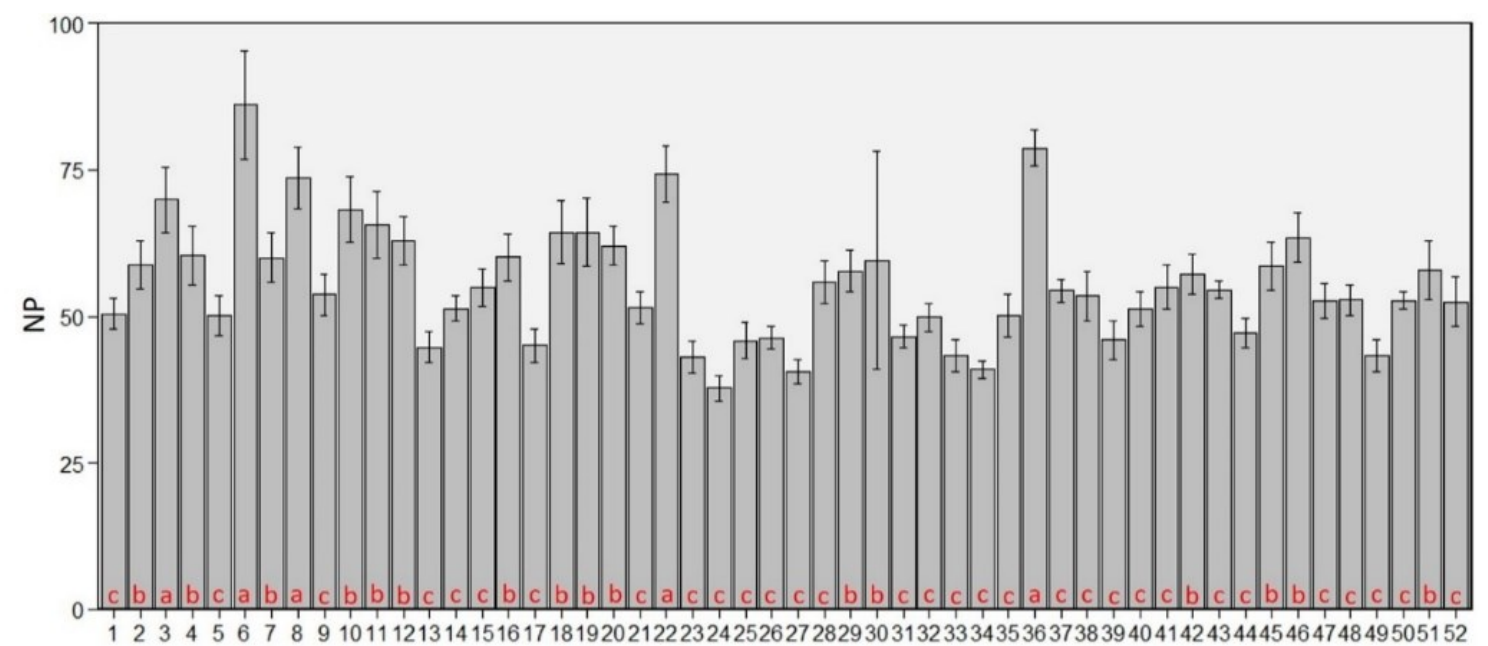

Figure 4 (a). Grouping of means by the Scott Knott test for the number of pods per plant.

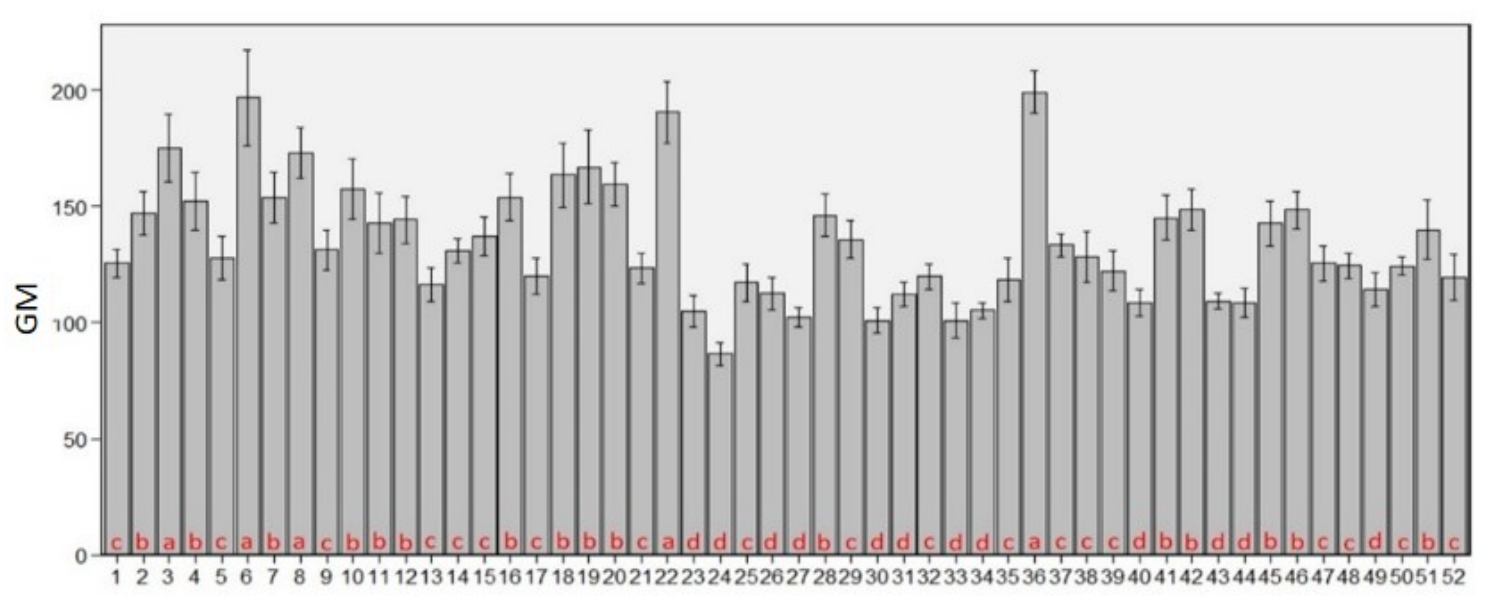

Figure 4 (b). Number of grains per plant. 


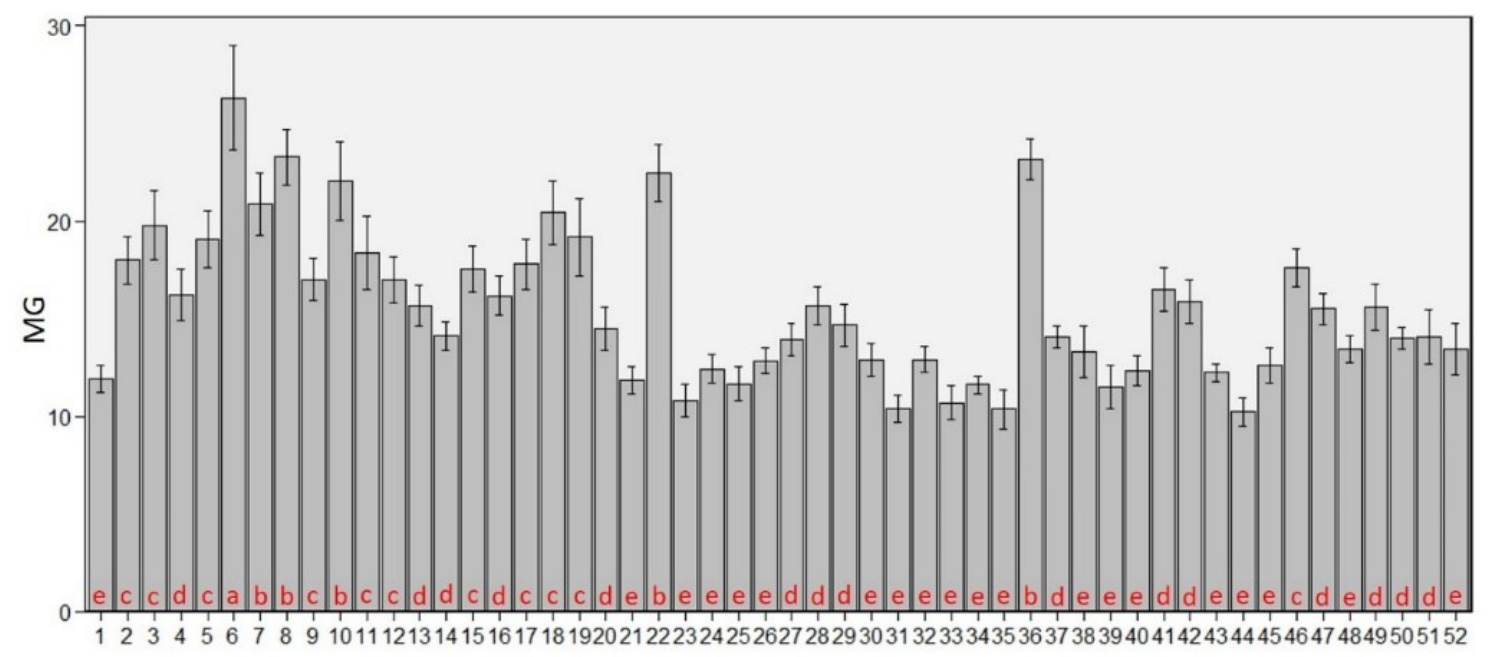

Figure 4 (c). Grain mass, for 52 soybean cultivars.

*Averages followed by the same lower case letter do not differentiate between themselves at 5\% probability. BMX Delta IPRO (1), DM 57i52 IPRO (2), P 95R90 IPRO (3), CZ 15B70 IPRO (4). BMX Zeus IPRO (5), BMX Raio IPRO (6), NS 5445 IPRO (7), P $95 R 30$ IPRO (8), DM 53 i54 IPRO (9), P 95Y02 IPRO (10), NEO 530 IPRO (11), NS 5258 RR (12), FTR 4153 IPRO (13), HO Amambay IPRO (14), BRS 5601 RR (15), NS 5700 IPRO (16), BRS 5804 RR (17), TMG 7058 IPRO (18), AG 3570 IPRO (19), P95R95 IPRO (20), BS 2606 IPRO (21), DM 5958 IPRO (22), BRS 6203 RR (23), CZ 26B42 IPRO (24), P96Y90 RR (25), AG 3590 IPRO (26), NS 6909 IPRO (27), HO Jacuí IPRO (28), NS 5909 RR (29), NS 6010 IPRO (30), BMX Fibra IPRO (31), FPS 1859 RR (32), TMG 7363 RR (33), C 2626 IPRO (34), HO Pirapó IPRO (35), SYN 1365 RR (36), TMG 7067 IPRO (37), BMX Compacta IPRO (38), M 6410 IPRO (39), SYN 15630 IPRO (40), M 5947 IPRO (41), NS 6601 IPRO (42), DM 66168 IPRO (43), LG 60174 IPRO (44), TMG 2364 IPRO (45), TMG 7061 IPRO (46), FPS 1867 IPRO (47), TMG 2165 IPRO (48), TMG 7260 IPRO (49), SYN 1561 IPRO (50), NEO 610 IPRO (51) and TMG 7368 IPRO (52).

For the thousand seed mass (figure 5 a) the best cultivars were BMX Zeus IPRO (5), BRS 5804 RR (17), BMX Raio IPRO (6), NS 5445 IPRO (7), P95R30 IRPO (8), P95Y02 IPRO (10), FTR 4153 IPRO (13). These characteristics of seed mass, are mainly influenced by the environmental conditions and number of pods, this result being very visible in the experiment, that the cultivars that presented greater number of pods were practically the same ones that presented greater grain mass and thousand seed mass. Grain yield (GY) (Figure $5 \mathrm{~b}$ ), showed that the cultivars with the highest yield were P 95R90

IPRO (3), BMX Raio IPRO (6), NS 5445 IPRO (7), P 95R30 IPRO (8), P 95Y02 IPRO (10), TMG 7058 IPRO (18) and DM 5958 IPRO (22). These cultivars have an early cycle, which results in a shorter period of field growing, in addition to having a greater number of pods, number of grains and a thousand seed mass. Although it presented low rainfall in the period, there may have been rains during periods of greatest importance for the crop. Yield is expressed through the interaction of genetics and environment, combined with management practices, which can maximize this yield (Da Silva et al., 2017).



Figure 5 (a). Thousand seed mass. 


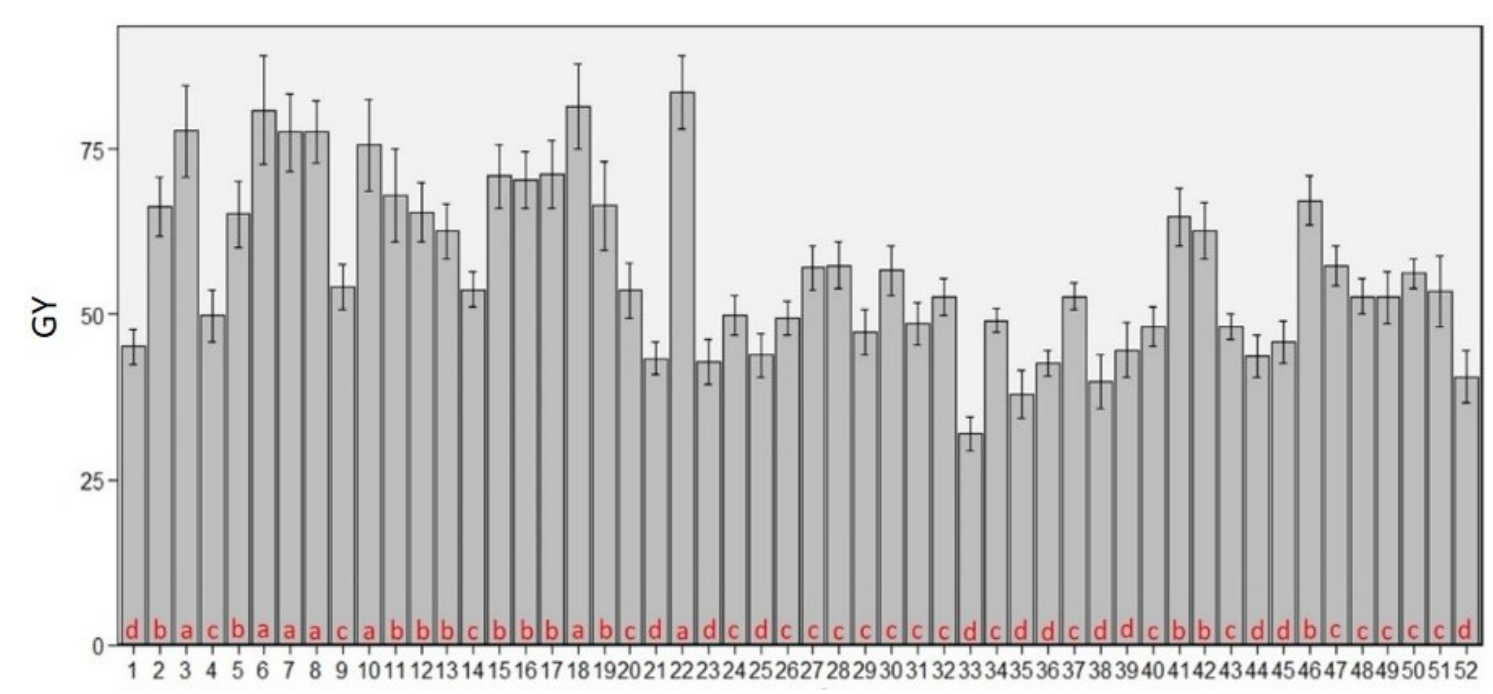

Figure 5 (b). Yield for 52 soybean cultivars.

* Averages followed by the same lower case letter do not differentiate between themselves at $5 \%$ probability. BMX Delta IPRO (1), DM 57i52 IPRO (2), P 95R90 IPRO (3), CZ 15B70 IPRO (4). BMX Zeus IPRO (5), BMX Raio IPRO (6), NS 5445 IPRO (7), P 95R30 IPRO (8), DM 53 i54 IPRO (9), P 95Y02 IPRO (10), NEO 530 IPRO (11), NS 5258 RR (12), FTR 4153 IPRO (13), HO Amambay IPRO (14), BRS 5601 RR (15), NS 5700 IPRO (16), BRS 5804 RR (17), TMG 7058 IPRO (18), AG 3570 IPRO (19), P95R95 IPRO (20), BS 2606 IPRO (21), DM 5958 IPRO (22), BRS 6203 RR (23), CZ 26 B42 IPRO (24), P96Y90 RR (25), AG 3590 IPRO (26), NS 6909 IPRO (27), HO Jacuí IPRO (28), NS 5909 RR (29), NS 6010 IPRO (30), BMX Fibra IPRO (31), FPS 1859 RR (32), TMG 7363 RR (33), C 2626 IPRO (34), HO Pirapó IPRO (35), SYN 1365 RR (36), TMG 7067 IPRO (37), BMX Compacta IPRO (38), M 6410 IPRO (39), SYN 15630 IPRO (40), M 5947 IPRO (41), NS 6601 IPRO (42), DM 66168 IPRO (43), LG 60174 IPRO (44), TMG 2364 IPRO (45), TMG 7061 IPRO (46), FPS 1867 IPRO (47), TMG 2165 IPRO (48), TMG 7260 IPRO (49), SYN 1561 IPRO (50), NEO 610 IPRO (51) e TMG 7368 IPRO (52).

Pearson's linear correlation for quantitative soybean characters (Figure 6), where yield showed a positive association for the variables number of pods (NP), number of grains (NG), grain mass (GM) and thousand seed mass (TSM), due to the dependence of these variables. For the number of pods (NP) there was a positive relationship for number of grains (NG), grain mass (GM) and thousand seed mass (TSM), and for the number of grains it is positively associated with grain mass (GM), and the latter correlates positively with the thousand seed mass (TSM).

The dendrogram for the quantitative characteristics (Figure 3b), the cultivars were stratified into groups with different coloring, those of the blue group are represented by the similarity between the cultivars BMX Fibra IPRO (31) and LG 60147 IPRO (44), BMX Delta IPRO (1) and BS 2606 IPRO (21), HO Amambay IPRO (14) and TMG 7067 IPRO (37), FPS 1859 RR (32) and TMG 2165 IPRO (48), BRS 6203 RR (23) and C2626 IPRO (34), and SYN 15630 IPRO (40) and DM 66 i68 IPRO (43).

The main characteristics for the equivalent cultivars were the number of pods, grain mass and thousand seed mass. For the red group, the cultivars that showed equivalence were 20 and 45 , also due to the grain mass and the thousand seed mass. For the orange group, the cultivars that showed similar were FTR 4153 IPRO (13) and TMG 7260 IPRO (49), DM 53i54 IPRO (9) and FPS 1867 IPRO (47), BMX Zeus IPRO (5) and BRS 5804 RR (17) in which the characteristics showed similarities for these cultivars were the grain mass, thousand seed mass and yield. For the green group, similar cultivars were NS 5445 IPRO (7) and P95Y02 IPRO (10), P95R90 IPRO (3) and AG 3570 IPRO (19), HO Jacuí IPRO (28) and NS 6601 IPRO (42), NS 5258 RR (12) and TMG 7061 IPRO (46).

Due to them presenting similar characterristics among the variables analyzed, mainly for the thousand grain mass and yield. For the purple colored group, only the cultivars BMX Raio IPRO (6) and DM 5958 IPRO (22) showed an affinity due to the similarity to the grain mass. The cultivar SYN 1365 RR (36) was dark blue in color due to its greater grain mass, when compared to other cultivars.

The decision tree (Figure 7), is a tool that shows determining characteristics for choosing the most productive cultivars, the variables number of grains (NG) and thousand seed mass (TSM), are the most determinant for decision making for the choice of cultivar that will result in higher yield. If the number of grains (NG) is less 
than 126 grains, another characteristic is analyzed, such as the thousand seed mass, if it is less than $107 \mathrm{~g}$, the number of grains is observed again, if the final yield is greater than 109 grains, the final yield will be 43 sacks per hectare. If it is less, the number of grains is analyzed, if it is less than 84 the final yield will be 24 sacks per hectare and if it is higher the yield will be 34 sacks per hectare. If the thousand seed mass is greater than $107 \mathrm{~g}$, but the number of grains is less than 90 , the final yield will be 38 sacks per hectare, if it is greater than 90 grains, and the thousand seed mass greater than 128 grams, yield will be 58 sacks per hectare, if lower, yield will be 48 sacks per hectare.



Figure 6. Pearson's linear correlation for agronomic characteristics of 52 soybean cultivars. Yield (GY), number of pods (NP), number of grains (NG), grain mass (GM) and thousand seed mass (TSM).

* Significant at $5 \%$ probability ** Significant at $1 \%$ probability.

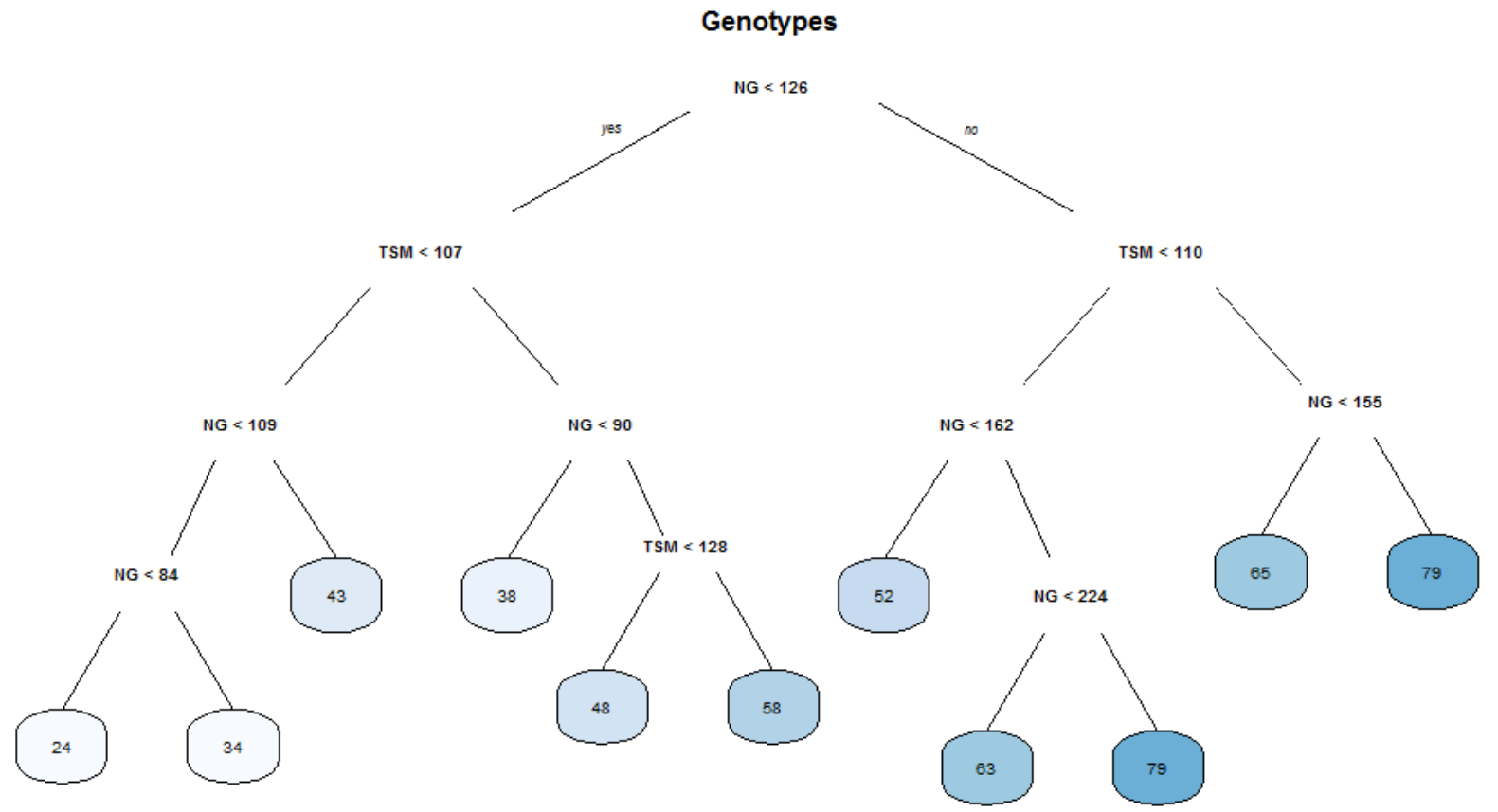

Figure 7. Decision tree for choosing soybean cultivars considering the variables number of grains (NG) and thousand seed mass (TSM). 
When the number of grains shows values greater than 126 grains, but if the thousand seed mass is less than 110 grams, the number of grains is evaluated again, if this shows a quantity of less than 126, the final yield will be 52 sacks per hectare. If the number of grains is greater than 224, yield will be 79 sacks per hectare, if less than this value, the final yield will be 63 sacks per hectare. If the cultivar shows a thousand seed mass greater than 110 grams and a number of grains greater than 155, the final yield will be 79 sacks, if the number of grains is smaller, the yield will be around 65 sacks per hectare. The cultivars that showed higher yield were P 95R90 IPRO (3), BMX Raio IPRO (6), NS 5445 IPRO (7), P 95R30 IPRO (8), P 95Y02 IPRO (10), TMG 7058 IPRO (18) and DM 5958 IPRO (22), with $57,53,58,64,54,56$ and 59 sacks per hectare respectively. For the rest of the cultivars the average production was between 48 to 58 sacks per hectare. For example, the cultivar P 95R30 IPRO (8) presented a number of grains of 173 , being greater than 126 , so the thousand seed mass was 134 grams, being greater than $110 \mathrm{~g}$.
Therefore, the number of grains, which was less than 155, will result in the final yield of approximately 65 sacks.

The variance components and genetic parameters (REML) were estimated for the soybean yield components for 52 cultivars (Table 2). Due to the phenotypic expression of the character, it is associated with the effects of the environment and genetic variation. Therefore, we tried to show the relationship between individual phenotypic variance $\left(\sigma^{2} P\right)$ and genotypic variance $\left(\sigma^{2} G\right)$, which was identified for grain yield (GY), number of pods (NP), number of grains (NG), grain mass (GM) and thousand seed mass (TSM). These characters were determined by $29.06 \%, 15.93 \%$, $24.25 \%, 32.60 \%$ and $59.12 \%$ from genetic effects respectively. Heritability reports the genetic variance existing in the phenotypic variance, in addition to indicating the experimental precision and reliability of the phenotype (Carvalho, 2017b). The broad sense heritability $\left(\widehat{H}^{2} g\right)$ conceptualizes the total genotypic effects, without considering the genotype $\mathrm{x}$ environment interaction.

Table 2. REML Variance components and genetic parameters.

\begin{tabular}{|c|c|c|c|c|c|}
\hline \multirow{2}{*}{$\begin{array}{l}\text { REML Variance } \\
\text { components }^{1}\end{array}$} & \multicolumn{4}{|c|}{ Characters $^{2}$} & \multirow[b]{2}{*}{ TSM } \\
\hline & GY & NP & NG & GM & \\
\hline$\sigma^{2} G$ & 86.07 & 79.39 & 550.74 & 13.18 & 249.68 \\
\hline$\sigma^{2} E$ & 210.01 & 418.89 & 1720.14 & 27.23 & 172.58 \\
\hline$\sigma^{2} P$ & 296.08 & 498.29 & 2270.89 & 40.42 & 422.26 \\
\hline$\hat{H}^{2} g$ & 0.29 & 0.15 & 0.24 & 0.32 & 0.59 \\
\hline$\hat{H}^{2} m g$ & 0.62 & 0.43 & 0.56 & 0.65 & 0.85 \\
\hline Aclon & 0.78 & 0.65 & 0.74 & 0.81 & 0.92 \\
\hline CVg (\%) & 17.08 & 16.08 & 17.44 & 23.43 & 13.76 \\
\hline CVe (\%) & 26.67 & 36.94 & 30.83 & 33.66 & 11.4 \\
\hline $\mathrm{CVr}$ & 0.64 & 0.43 & 0.56 & 0.69 & 1.2 \\
\hline Overall mean & 54.31 & 55.4 & 134.52 & 15.5 & 113.82 \\
\hline
\end{tabular}

${ }^{1} \sigma^{2} G$ : genotypic variance; $\sigma^{2} E$ : residual variance; $\sigma^{2} P$ : individual phenotypic variance; $\hat{H}^{2} g$ : broad sense heritability for the total genotypic effects; $\hat{H}^{2} m g$ : heritability of the genotype mean; Aclon: Accuracy, $\mathrm{CVg}(\%)$ : genotypic variation coefficient; $\mathrm{CVe}(\%)$ : residual coefficient of variation; Overall mean: overall mean of the study.

${ }^{2}$ Yield (GY), number of pods (NP), number of grains (NG), grain mass (GM) and thousand seed mass (TSM).

For grain yield (GY), heritability showed that $29 \%$ is genetic effect and $71 \%$ is environment, that is, a characteristic highly influenced by environmental conditions, such as climate, crop practices, fertility, among others. The character number of pods per plant shows that $15 \%$ is genetic and $85 \%$ is an effect of the environment. For the number of grains, $24 \%$ of this characteristic is a genetic effect and $76 \%$ was an effect of the environment. The grain mass characteristic showed a genetic effect of $32 \%$ and an environmental effect of $68 \%$. For the characteristic thousand seed mass (TSM), $59 \%$ is of genetic effect and $41 \%$ is of environmental effect. This characteristic is one of the most stable, being defined in the programs of soybean breeding, in order to present approximate mass varying little by the adversities of growing, mainly in conditions of water deficiency (Follmann et al., 2016). 


\section{Conclusions}

The most productive cultivars were P95R90 IPRO, BMX Raio IPRO, NS 5445 IPRO, P95R30 IPRO, P95Y02 IPRO, TMG 7058 IPRO and DM 5958 IPRO.

Yield correlates positively with the number of pods, number of grains, grain mass and thousand seed mass.
The dendrogram for the quantitative characteristics and the decision tree showed that the formation of the groups and the grain yield were determined mainly by the grain mass and the thousand seed mass.

Among the components of variance and genetic parameters, the variables thousand grain mass, grain mass and yield are influenced by $59 \%$, $32 \%$ and $29 \%$ respectively by genetic effects.

\section{References}

AGUIAR, A.O.; SOARES, C.M.S.; IBIAPINA, A.; GUEDES, E.H.S.; ALMEIDA, L.J.; PELUZIO, J.M.; MARTINS, G.A.S. 2020. Optimization of desacidification of soybean oil used for biodiesel production in Tocantins. Research, Society and Development. v. 4, n. 1, p. 651-661.

AGUILA, L.S.H.; ROANI, T.D.F.M.; GEHLING, R.K.; JUNIOR, F.D.J.V.; AGUILA, J.S. 2020. Rio Grande do Sul-REC 101: épocas de semeadura para genótipos de soja. Brazilian Journal of Animal and Environmental Research, v. 3, n. 2, p. 654-662.

CARVALHO, I.R.; KORCELSKI, C.; PELISSARI, G.; HANUS, A.D.; ROSA, G.M.; 2013. Demanda hídrica das culturas de interesse agronômico. Enciclopédia Biosfera, Centro Científico Conhecer - Goiânia, v.9, n.17; p.

CARVALHO, I.R.; NARDINO, M.; SOUZA, V.Q. 2017a. Melhoramento e Cultivo da Soja. 1. ed. Porto Alegre: Cidadela, v. 100. 366p.

CARVALHO, I.R.; NARDINO, M.; DEMARI, G.; PELEGRIN, A.J.; FERRARI, M.; SZARESKI, V.J.; OLIVEIRA, V.F.; BARBOSA, M.H.; SOUZA, V.Q.; OLIVEIRA, A.C.; MAIA, L. 2017b. Components of variance and inter-relation of important traits for maize (Zea mays) breeding. Australian Journal Crop Science, v. 11, p. 982-988.

CARVALHO, I.R.; SZARESKI, V.J.; NARDINO, M.; VILLELA, F.A.; SOUZA, V.Q. 2018. Melhoramento e produção de sementes de culturas anuais - Soja, Milho, Trigo e Feijão. 1. ed. Saarbrücken, Germany: Ommi Scriptum Publishing Group, v. 50. 229p.

CONAB (2020). Companhia Nacional de Abastecimento. Acompanhamento da safra brasileira: August. Available at http://www.conab.gov.br, accessed on 08/25/2020.

DA SILVA, C.M.; OLIVEIRA, Z.B.; KNIES, A.E.; DE SOUZA, I.J.; LINK, T.T. 2017. Análise dos componentes do rendimento de diferentes cultivares de soja em Cachoeira do Sul. v.40, Edição Especial: II mostra de Projetos da UFSM - Revista do Centro de Ciências Naturais e Exatas - UFSM.

DORNELES, J.B.; CARVALHO, I.R.; MARTINS, T.S.; MOURA, N.B.; SILVA, J.A.G.; LAUTENCHLEGER, F. 2020. Two decades of national registry of soybean cultivars: updates and perspectives. Communications in Plant Sciences, v. 10, p. 1-12.

FOLLMANN, D.N.; SOUZA, V.Q.; CARGNELUTTI FILHO, A.; NARDINO, M.; CARVALHO, I.R.; DEMARI, G.; MEIRA, D.; SILVA, A.D.B.; MEIER, C. 2016. Agronomic performance and stability of soybean cultivars in not preferred time. International Journal of Current Research, v. 08, p. 37665-37670. 
GUimarãeS, R.M.; LIMA, M.C.P.M.; EGEA, M.B. 2016. Produção De Patê Vegetal A Partir De Subproduto De Soja. Informe Goiano, v. 1, n. 1.

KLAUMANN, A.A; WERLANG, L.; SCHÖNHALS, H.; BALZAN, F.; BECKER, N.D.; MÜHL, F.R.; FELDMANN, N.A.; RHODEN, A.C.; BALBINOT, M. 2015. Avaliação da Qualidade de Sementes de Soja através do teste de Peroxidade. $4^{\circ}$ Simpósio de Agronomia e Tecnologia em Alimentos. Centro Universitário FAI.

Navarro, J.H.M.; Costa, J.A. 2002. Contribuição relativa dos componentes do rendimento para produção de grãos em soja. Pesquisa Agropecuária Brasileira, v. 37, n. 3, p. 269-274.

SCHAPARINI, L.P; FONTANA, D.C.; DALMAGO, G.A.; RODIGHERI, G.; FERNANDES, J.M.C.; SANTI, A.; VARGAS, P.R. 2020. Analise comparativa entre índices de vegetação e sua relação com o balanço hídrico em soja. Agrometeoros, v. 27, n. 1.

SILVA, A.V.S.; SILVA, C.M.; PAVAN, B.E.; PESSOA, W.R.L.S.; MIELEZRSKI, F. 2018. Época de Semeadura $x$ grupos de maturação nos componentes de rendimentos de soja. Cultura Agronômica, Ilha Solteira, v.27, n.1, p.44-56.

STRECK, E.V; KÄMPF, N.; DALMOLIN, R.S.D.; KLAMT, E.; NASCIMENTO, P.D.; SCHNEIDER, P.; PINTO, L.F.S. 2008. Solos do Rio Grande do Sul. Porto Alegre: UFRGS: EMATER/RS-ASCAR.

SZARESKI, V.J; CARVALHO, I.R.; DEMARI, G.; PELISSARI, G.; PELEGRIN, A.J.; BARBOSA, M.H.; CORAZZA, T.; SANTOS, N.L.; MARTINS, T.; NARDINO, M.; PEDO, T.; SOUZA, V.Q.; AUMONDE, T.Z. 2018. Path analysis of agronomic traits in soybean cultivars with determinate and indeterminate growing habits. Australian Journal Crop Science, v. 12, p. 531-538.

ZANON, A.J; SILVA, M.R.; TAGLIAPIETRA, E.L.; CERA, J.C.; BEXAIRA, K.P.; RICHTER, G.L.; JUNIOR, A.J.D.; ROCHA, T.D.M.; WEBER, P.S.; STRECK, N.A. 2018. Ecofisiologia da Soja Visando Altas Produtividades. 1. ed. Santa Maria. 